\title{
Taphonomic differentiation of Oxfordian ammonites from the Cracow Upland, Poland
}

\author{
Agata Jurkowska • Bogusław Kołodziej
}

Received: 15 May 2012/ Accepted: 16 July 2012/Published online: 19 August 2012

(C) The Author(s) 2012. This article is published with open access at Springerlink.com

\begin{abstract}
Taphonomic analysis of Lower and Middle Oxfordian ammonites from the Cracow Upland, southern Poland (localities at Podłęże, Zalas, Młynka) revealed differences in ammonite preservation. The studied ammonites, usually termed as external and internal moulds, show a more complex state of preservation. In the Middle Oxfordian glauconitic marls, ammonites are preserved as internal moulds with neomorphic calcite shells showing relics of the original internal structure. In the Middle Oxfordian platy peloidal limestones, ammonites are preserved mostly as external moulds, without septal suture, however under microscope might show relics of internal whorls and septa and/or subtle differences in sediment filling phragmocone chambers. In sponge-microbial bioherms and biostromes, ammonite internal moulds have shells, which in contrast to ammonites from glauconitic marls are not strictly neomorphic ones, but originated by shell dissolution and subsequent filling of moldic porosity by calcite cement. In sponge-microbial nodular limestones, the ammonites are strongly deformed and the outer wall is usually removed by dissolution under pressure. Other important taphonomic differences include the rate of compaction (highest in platy limestones), sedimentary infillings, microborings, encrustations and preservation of siphuncular tubes. The majority of the ammonites appear to be phragmocones; aptychi in all facies are rare. Siphuncular tubes are fossilized exclusively in oppeliids, only in specimens from glauconitic marls and platy limestones,
\end{abstract}

\footnotetext{
A. Jurkowska $(\varangle) \cdot$ B. Kołodziej

Institute of Geological Sciences, Jagiellonian University, ul. Oleandry 2a, 30-063 Kraków, Poland

e-mail: jurkowska.a@gmail.com

B. Kołodziej

e-mail: boguslaw.kolodziej@uj.edu.pl
}

although their other taphonomic attributes are different. Tubes seem to have fossilized due to microbially mediated phosphatization that could be favoured by a set of parameters which operated rather at the scale of ammonoid carcasses: closed, poorly oxygenated conditions, and reduced pH. Taphonomic processes were controlled by the sedimentary environment (fragmentation, sedimentary filling, phosphatization of siphuncular tubes), as well as by early and late diagenesis (neomorphic transformation, dissolution, cementation, compaction) influenced by lithology.

Keywords Ammonites - Taphonomy - Phosphatization · Oxfordian · Polish Jura Chain · Cracow Upland

Kurzfassung Die taphonomische Analyse von Ammoniten des unteren und mittleren Oxfordium im Krakauer Hochland, Südpolen (Lokalitäten Podłęże, Zalas, Młynka) zeigt faziesabhängige Unterschiede in der Erhaltung der Ammoniten. In glaukonitischen Mergeln des mittleren Oxfordium sind Ammoniten als Steinkerne mit neomorpher Kalzitschale erhalten und zeigen Reste der ursprünglichen internen Struktur. In plattigen, gebankten peloidalen Kalksteinen gleichen Alters sind Ammoniten überwiegend als externe Abformungen ohne Lobenlinien erhalten, die häufig Reste inerer Windungen mit Kammern und geringfügige Unterschiede in der Sedimentfüllung zeigen. In Schwamm/ Mikroben Biohermen und Biostromen haben die Steinkern der Ammoniten eine "diagenetische" Schale, die im Gegensatz zu den Ammoniten aus den glaukonitischen Mergeln nicht neomorph ist, sondern ein Ergebnis der Auflösung der Schale und nachfolgender Füllung des Hohlraums durch Kalzitzement. In Schwamm/Mikroben Knollenkalken sind die Ammoniten stark deformiert und die äußere Wand ist meist weggelöst. Andere bemerkenswerte Unterschiede in der Taphonomie bestehen in der 
Kompaktionsrate (die am höchsten in plattigen Kalksteinen ist), Sedimentfüllungen, Mikrobohrungen, Inkrustationen und die Erhaltung der Siphonen. Bei den meisten Ammonitenresten handelt es sich um Phragmokone; Aptychen sind in allen Faziesbereichen selten. Siphonen sind ausschließlich Oppeliiden erhalten, und ausschließlich bei Ammoniten aus den glaukonitischen Mergeln und plattigen Kalksteinen, auch wenn die Ammoniten in anderen taphonomischen Eigenschaften abweichen. Die Siphonen haben sich offenbar durch eine mikrobiell gesteuerte Phosphatisierung erhalten, die bevorzugt in einem geschlossenen, sauerstoffarmen Milieu mit reduzierten $\mathrm{pH}$ Wert stattfand, z.B. in einem Ammonitenkadaver. Die taphonomischen Prozesse wurden vom Sedimentationsmilieu kontrolliert (Sedimentfüllung, Fragmentierung, Phosphatisierung der siphuncularen Röhren), so wie von früher und später Diagenese (Lösung, Kompaktion), kontrolliert von lithologischen Prozessen.

Schlüsselwörter Ammoniten · Taphonomie . Phosphatisierung · Oxfordium · Krakauer Hochland . Südpolen

\section{Introduction}

Research in taphonomy has increased significantly in recent years and has demonstrated its usefulness in deciphering biostratinomic (pre-burial) and diagenetic history of subfossil and fossil biota (Brett and Baird 1986; Speyer and Brett 1988; Behrensmeyer et al. 2000; Allison and Bottjer 2011, and references therein).

Taphonomic studies of ammonites provide important data for assessing their life history, ecological and depositional conditions, as well as the diagenetic history of host deposits (e.g. Seilacher et al. 1976; Maeda and Seilacher 1996; Fernández-López and Meléndez 1995, 2004, Fernández-López 2007, 2011; Wani 2003; Olóriz et al. 2004; Lukeneder 2005; Olivero 2007; Maeda et al. 2010). Detailed taphonomic analyses have been applied in sequence stratigraphy (Fernández-López 2000, 2007, 2011; Courville and Collin 2002).

Ammonites in Oxfordian limestones and marls of the Polish Jura Chain (Cracow-Częstochowa Upland) are common, and have been the subject of numerous studies focussed on fine-resolution biostratigraphy and palaeogeography (e.g. Matyja and Tarkowski 1981; Głowniak 2002, 2006; Głowniak and Matyja 2006; Matyja and Wierzbowski 2006). However, taphonomic studies have been rarely performed (Tarkowski 1986).

This paper presents results from taphonomic studies of ammonites from the main lithofacies of the Lower and Middle Oxfordian of the southern part of the Cracow
(Kraków) Upland. Ammonites from analysed sediments have been termed in the biostratigraphic papers as internal and external moulds. However, detailed studies revealed that preservation of these ammonites shows more complex modes (Jurkowska 2008).

\section{Geological setting}

The studied material comes from the Lower and Middle Oxfordian rocks from the Cracow Upland, which is the southern part of the Polish Jura Chain (Fig. 1). This unit belongs to the Silesian-Cracow Monocline slightly inclined to ENE. Oxfordian limestones and marls (up to $250 \mathrm{~m}$ in Cracow region), including well-outcropped sponge-microbial buildups (sponge megafacies), were developed on the northern Tethyan shelf. They usually cover Callovian siliciclastics, marls and limestones. The uppermost Callovianlowermost Oxfordian interval is condensed and contains reelaborated ammonites (Giżejewska and Wieczorek 1977; Matyja and Tarkowski 1981; Ogg et al. 1991; Matyja and Wierzbowski 2006; Dembicz and Praszkier 2007).

The Lower Oxfordian rocks are developed as marls and marly limestones. Shallowing-upward transition from the Lower to Middle Oxfordian is dominated by thin- to medium-bedded limestones (local name: platy limestones), dominated by peloidal texture, intercalated with thin marly layers. The Middle and Upper Oxfordian is represented mainly by two facies: (1) thick-bedded limestones (local name: bedded limestones), usually sponge-microbial biostromes with common cherts, and (2) massive (biohermal) sponge-microbial limestones (local name: rocky limestones) (Dżułyński 1952; see also Matyszkiewicz 1997; Matyszkiewicz et al. 2012). Differentiated Palaeozoic

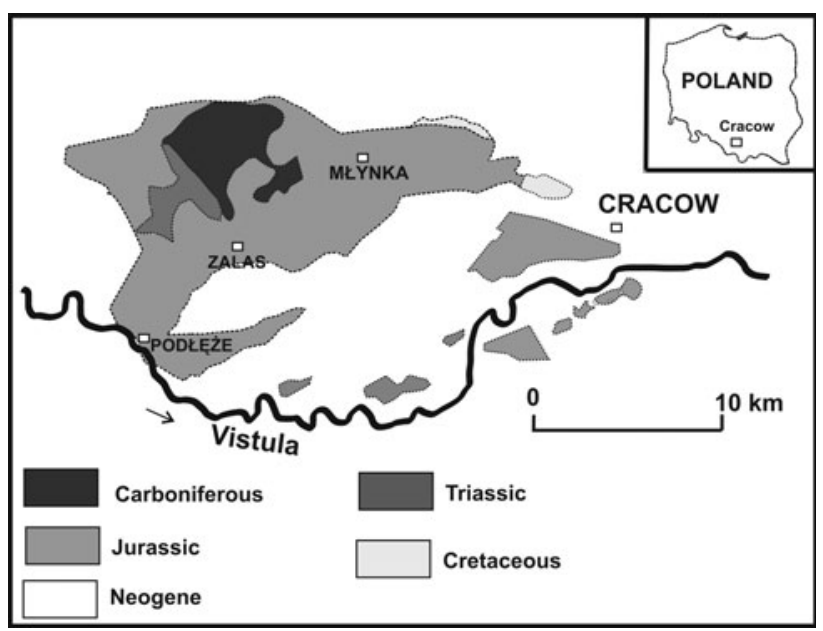

Fig. 1 Sample location on a geological map (Gradziński 1993). a Podłęże, b Zalas, c Młynka (see Fig. 2) 
subsurface structure, pre-Oxfordian topography, synsedimentary tectonics and local aggregational growth of carbonate buildups resulted in strong lateral and vertical variability of Late Jurassic successions (Matyszkiewicz et al. 2012, and literature therein).

Ammonite biostratigraphy of the Lower Oxfordian (Mariae and Cordatum zones) of the Cracow Upland was presented by Głowniak and Matyja (2006) and follows Cariou et al.'s (1997) scheme based on boreal ammonites. Głowniak (2002) proposed the biostratigraphic division of the Middle Oxfordian based on the Submediterranean taxa.

\section{Materials and methods}

The studied Lower and Middle Oxfordian ammonites come from three localities west of Cracow, namely Podłęże, Młynka and Zalas (Fig. 1).

\section{Podłęże (Fig. 2a)}

The Upper Jurassic profile begins with the Lower Oxfordian Mariae zone developed as white, marly limestones with abundant ammonites, belemnites and sponges (Giżejewska and Wieczorek 1977; Hoffmann 1983). The studied ammonites are mostly from Hoffmann's (1983) collection, housed at the Institute of Geological Sciences, Jagiellonian University. They come from two levels of Middle Oxfordian glauconitic marls, at present poorly exposed. Hoffmann (1983) attributed these marls to the lower part of the Antecedens zone. Hoffmann (1983) found some biostratigraphic gaps, however according to Kin (2008) it is possible to distinguish there the Paturattensis, Ouatius and Arkelli subzones. The profile ends with the lower part of Transversarium zones represented by platy limestones (Hoffmann 1983; Kin 2008).

\section{Zalas (Fig. 2b)}

In the quarry of ryodacites in Zalas, a well-known Jurassic section usually begins with Callovian siliciclastics covering transgressively Permian rhyodacites. Oxfordian marls lay above Callovian or locally directly on rhyodacites (Matyszkiewicz et al. 2007). The thickness of Lower and Middle Oxfordian rocks is variable, up to $18 \mathrm{~m}$ (Matyja and Tarkowski 1981). The Lower Callovian consists of siliciclastics, sandy limestones and crinoidal limestones, and the Upper Callovian is represented by deeper-water ferromanganese stromatolites and the condensed uppermost Callovian by marls (Giżejewska and Wieczorek 1977; Matyja 2006). Lower Oxfordian is also stratigraphically condensed, developed as yellow, pink and grey marls with sponges and ammonites representing the Mariae zone
(Giżejewska and Wieczorek 1977; Dembicz and Praszkier 2007) and Bukowski, Costicardia and Cordatum subzones of the Cordatum zone (Matyja and Tarkowski 1981). Marls contain abundant fossils, mainly ammonites, belemnites and brachiopods. Above occurs the complex of spongemicrobial bioherms, biostromes and interbedded grey marls (ca. $10 \mathrm{~m}$ ) representing the Middle Oxfordian Tenuicostatum subzone of the Plicatilis zone (Giżejewska and Wieczorek 1977; Matyja and Tarkowski 1981). Locally, in the Cordatum zone, sponge-microbial limestones have nodular appearance and reddish colour (Matyja and Tarkowski 1981).

Młynka (abandoned quarry in the Village of Nielepice; Fig. 2c)

Callovian siliciclastics, followed by carbonates, are overlaid by the Lower Oxfordian (Cordatum zone; Głowniak 2006) represented by grey marls with abundant ammonites and sponges. Middle Oxfordian is developed as thin-, midand locally thick-bedded, peloidal wackestones with thin marly intercalations (up to ca. $4 \mathrm{~cm}$ thick) (Plicatilis zone), up to $15 \mathrm{~m}$ in thickness (Głowniak 2006). These limestones exhibit peloidal texture typical of platy limestones sensu Dżułyński (1952). To avoid confusion with bedded limestones sensu Dżułyński (1952), the local, traditional term "platy limestones" is used even in their upper part in Młynka where they are mid- to thick-bedded. Platy limestones are covered by sponge-microbial bioherms and related detrital limestones (Buckmani subzone of the Transversarium zone) (Hoffmann and Matyszkiewicz 1989; Głowniak and Matyja 2006). In the upper part of the platy limestones a thin horizon of glauconitic marls was recognized (Jurkowska 2008).

The ammonites selected for taphonomic studies come from the Lower (but not lowermost) Oxfordian grey marls (Młynka, Zalas), Middle Oxfordian glauconitic marls (Podłęże), platy peloidal limestones (Młynka), spongemicrobial bioherms (Młynka, Zalas), sponge-microbial biostromes and sponge-microbial nodular limestones (Zalas).

During the fieldwork about 300 specimens were collected; another 40 came from the museum collection. They were analysed on natural and cut surfaces, and 65 thin sections were analysed by binocular and petrographic microscopes. Fifteen thin sections were observed by scanning electron microscope (SEM, Hitachi S-4700). In the framework of cathodoluminescence (CL) studies of Oxfordian deposits (Kołodziej et al. 2011), also five thin sections with ammonites were analysed with Carl Zeiss Jena long-distance petrographical microscope (JENAPOL 1.4/910) with a Cambridge Image Technology (CITL) 8,300 Mk III cold cathode instrument. 
marls

属舟 sponge-microbial biostroms

돌 platy limestones

鼻 sponge-microbial bioherms

$\square$ detrial limestones

clays

glauconitic marls

$\approx$ nodular limestones

ammonites

1,2,3,4,5 studied lithofacies

\section{Młynka}

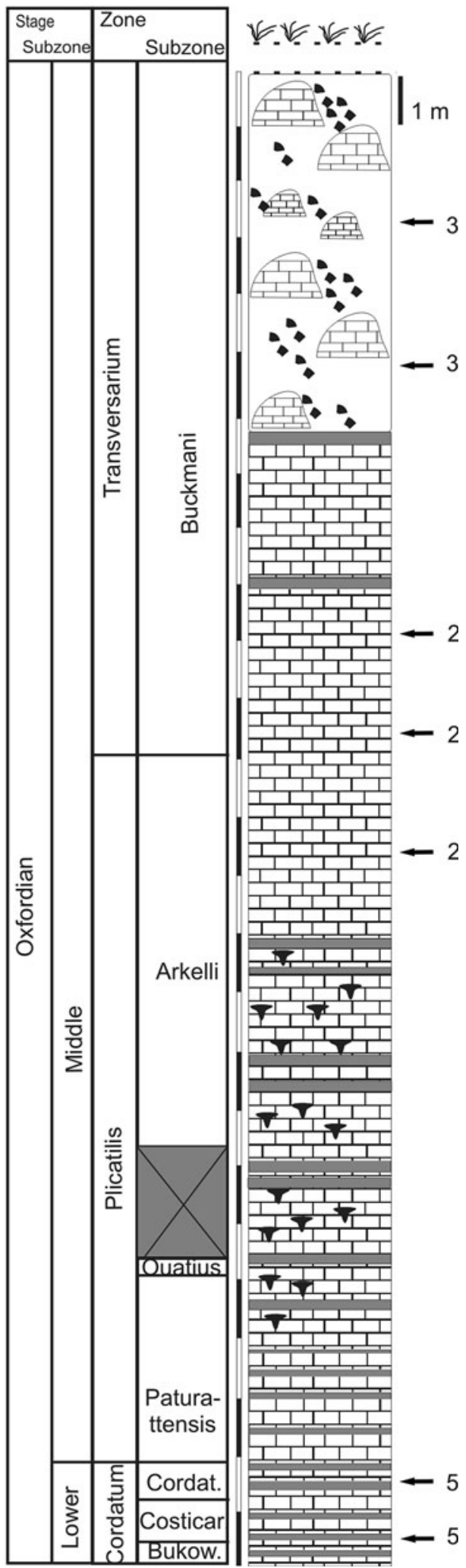

B

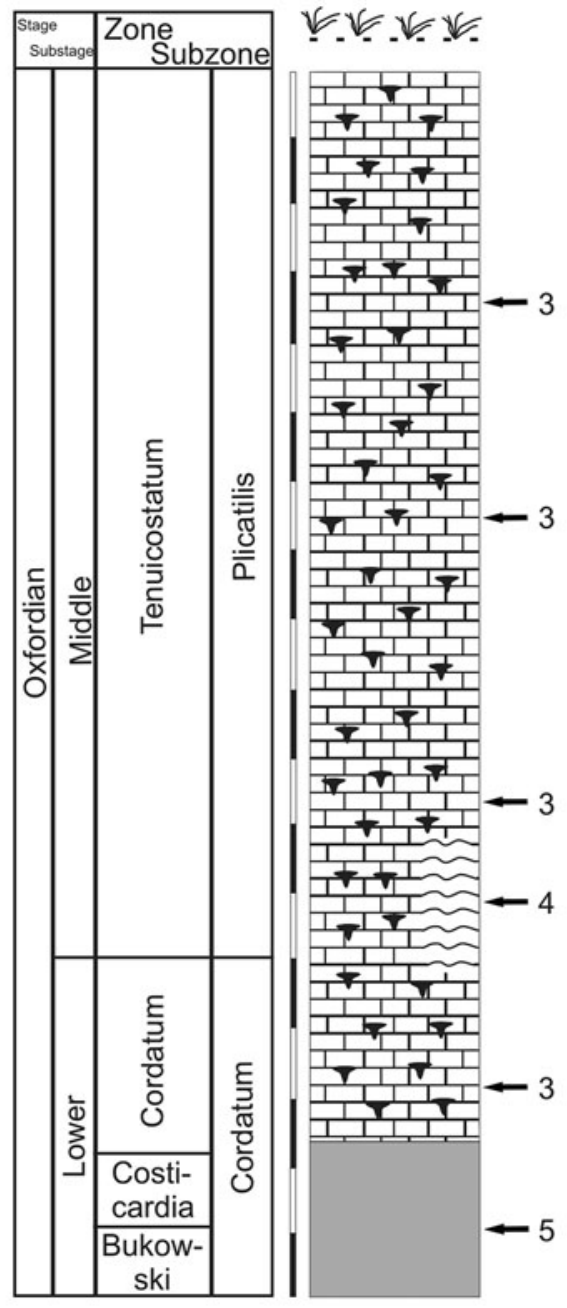

Zalas
A

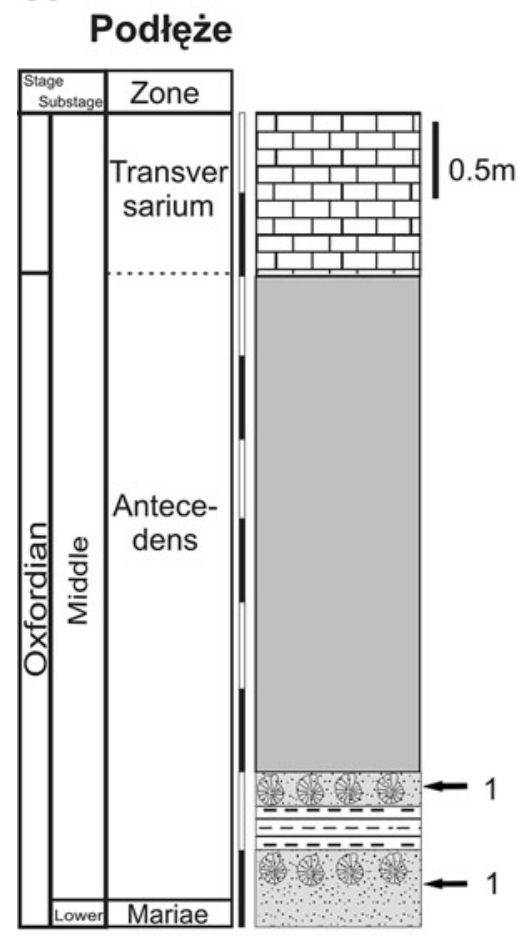

Fig. 2 Generalized studied sections. a Podłęże (after Hoffmann 1983). b Zalas (after Matyja and Tarkowski 1981; modified and simplified). c Młynka (biostratigraphy after Głowniak and Matyja 2006). Numbers 1 to
5 at the right side of lithological logs refer to lithologies described in the paper. 1 glauconitic marls, 2 platy limestones, 3 sponge-microbial bioherms and biostromes, 4 sponge-microbial nodular limestones, 5 grey marls 


\section{Results}

Ammonoid preservation

Five main facies were studied in terms of ammonoid occurrence (relative abundance of specimens) and preservation style: general type of shell preservation (type of mould, type of diagenetically altered shell), sedimentary filling of shells, presence or lack of encrustations and microborings, preservation of siphuncular tube, fragmentation, compaction and other deformations. In all studied facies the majority of the ammonites appear to be phragmocones, aptychi being rare.

Glauconitic marls (Podłęże) (Figs. 3, 8c, d)

Ammonites are abundant, represented mostly by Perisphinctidae, Oppeliidae and rare Cardioceratidae (Hoffmann 1983; Kin 2008). Ammonites attain diameters of up to $25 \mathrm{~cm}$. Because the present state of outcrops is poor, and because most of the specimens studied by us from museum are devoid of surrounding deposit, some information below dealing with macroscopic features of ammonites and host deposits are taken from Hoffmann (1983). The specimens available to us were well preserved, but Hoffmann (1983) has recognized that ammonites are commonly compacted, and large forms are usually fragmented, while small ones are well preserved. Ammonites are preserved as internal moulds with neomorphic calcite shells. Sediment filling chambers is similar to the host sediment. Ammonites are associated with numerous belemnites, less commonly brachiopods, bivalves, sponges and single gastropods (Hoffmann 1983). Glauconitic marls analysed in thin sections are mostly peloidal wackestones with abundant planktonic foraminifera, visible mostly under CL microscope (Kołodziej et al. 2011). Other foraminifera and sponge spicules occur rarely. Microbial crusts are absent on ammonite shells, or, if present, microbial crusts with poorly defined lamination occur on single (Fig. 3a) or both sides of specimens. Hoffmann (1983) observed microbial encrustations, mostly on specimens from the upper part of the analysed marls. Some ammonites were also encrusted on both sides by serpulids and bryozoans. Two specimens from Hoffmann's collection are clearly corroded on one side (Fig. 3b).

No microbialites were found within ammonite shells, except for well-developed dendritic microbial structures (Frutexites Maslov) recognized in two chambers of two specimens (Fig. 3c). The first chamber was partly filled with peloidal wackestone. In the second one Frutexites was embedded in matrix. About $40 \%$ of shells contain sparfilled chambers, but rarely more than $1 / 4$ of chambers in one phragmocone. The cement consists of three or two generations. Usually thin coating of siliceous cement occurs as the first generation. Two other generations consist of radiaxial and blocky calcite (Fig. 3f, h). Geopetal structures were also recognized.

The neomorphic calcite shells show relics of the original structure (Fig. 3d, e, g). Double-layer shell structure unequivocally indicates that the shells were not dissolved as observed commonly in other facies, but are built by neomorphic calcite spar. Locally, the shell shows microlamination (Fig. 3g). Usually the calcite crystals building the septa differ from those in the wall (Fig. 3f), but still in some of septa there are relics of their original structure (Fig. 3g). This indicates that at least some, if not most, septa were not dissolved, but aragonite has been transformed neomorphically into calcite. Very rare and only some skeletal elements were locally dissolved, and moldic porosity was filled with micrite. Siliceous cement usually occurs as the first cement generation (if there is no sedimentary filling), but ammonite shells are very rarely, and only locally, silicified. Clear differences in wall ornamentation were observed in some ammonites. Inner surface of wall of outer whorls reveals "smoothed" ornamentation (Fig. 3d, e). Under CL, ammonite shells show bright redorange luminescence.

Phosphatized siphonal tubes were recognized in 15 specimens of oppeliids from Podłęże and Młynka. They were attached to the wall or fragmented (Fig. 8c). SEM observations of seven tubes (including those from Młynka) revealed hollow globules (bacterial structures?) within and on the outer surface of three tubes (Jurkowska 2008) (Fig. 8d). Energy-dispersive spectroscopy (EDS) analyses revealed that tubes are composed of francolite (calcium phosphate).

Platy limestones (Młynka) (Figs. 4, 8a, b)

Ammonites are represented mostly by Perisphinctidae and rare Taramelliceratidae (Głowniak and Matyja 2006). Ammonites attain diameters up to $100 \mathrm{~cm}$. Based on macroscopic observations of the outer surface of ammonites (easily extracted from the host sediment), they appear to be preserved as external moulds, because the skeletal elements, wall and septal suture are absent (Fig. 4a). However, observations of cut specimens and thin sections indicate that some ammonites revealed relics of walls of inner whorls (Fig. 4b) and even suture line. These relicscalcite cement filling dissolved skeletal element-are not well recognizable as in sponge-microbial limestones. More detailed microscopic studies are required to estimate the abundance of shell relics. Moreover, subtle differences in sediment filling phragmocone chambers indicate the previous location of skeletal elements in some specimens (Fig. 4d). Sediment filling-peloidal wackestone to 

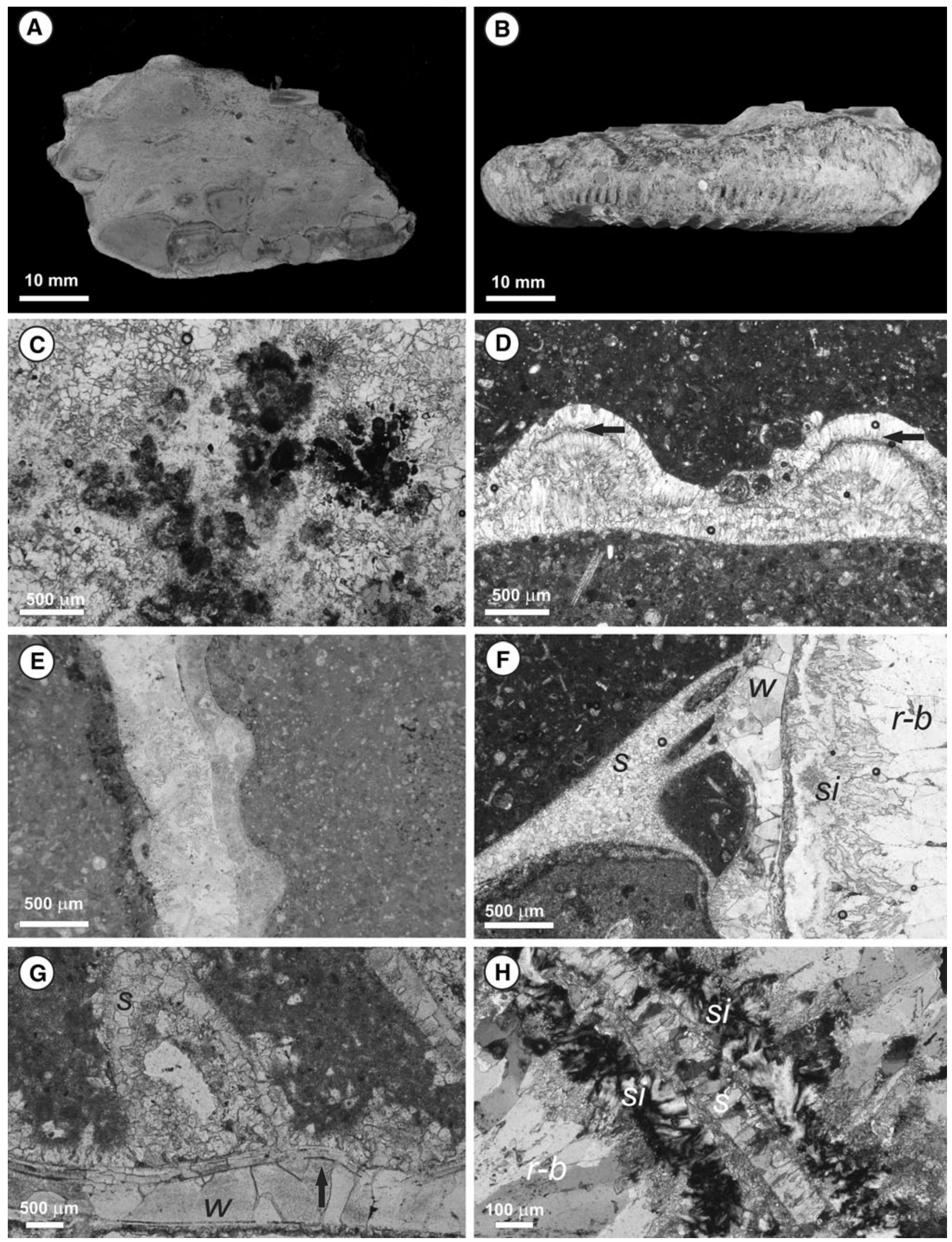
4Fig. 3 Taphonomic features of ammonites from the Middle Oxfordian glauconitic marls, Podłęże. a Poorly laminated microbialites on one side of the ammonite surface. Inverted geopetal structures indicate that ammonites were reworked after sedimentary infills. b Corroded ammonite surface. c Frutexites structure within ammonite chamber. d Differences in external and internal ("smoothed") wall ornamentation. Arrows show dark line between two layers of neomorphic shell. e Double-layer structure of neomorphic shell. f Different preservation of wall $(w)$ and septum $(s)$; si siliceous, $r-b$ radiaxial-blocky calcite cement. $\mathbf{g}$ Different preservation of wall $(w)$ and septum $(s)$. Note microlamination of pseudosparite calcite in wall. $\mathbf{h}$ Two generations of cements: $s i$ siliceous cement, $r$ - $b$ radiaxial-blocky calcite cement, $s$ septum

packstone with fine bioclasts-shows similarities to the host sediment, or grains are slightly smaller (Fig. 4c, d). No empty chambers or chambers filled only with calcite spar were observed.

Epibionts are not common: nubeculariid foraminifera, serpulids, agglutinating worm tubes Terebella lapilloides Münster, and-on larger moulds-oysters. Microbial encrustations were not recognized here.

Most of ammonites appear to occur parallel to bedding. Chaotic concentrations of small ammonites (up to $5 \mathrm{~cm}$ ) or their remains (also fragmented larger forms) were observed locally (Fig. 4f). However, no reelaborated (sensu Fernández-López 2007, i.e. exhumed and displaced) ammonites were recognized. Ammonites from platy limestones show the highest degree of compaction (Fig. 4e). Some ammonites are visible within the rock only because of the fossilized siphuncular tubes (Fig. 8a). Similarly, as in glauconitic marls, phosphatized siphuncular tubes occur only in the specimens from the family Oppeliidae. They are common, non-fragmented or fragmented and scattered within the chamber. Most of siphuncular tubes are compressed, with crack along the middle part (Fig. 8b), but some are still round in the transverse section.

In contrast to the Lower Oxfordian grey marls, the marly intercalations within platy limestones do not contain ammonites; however, sampling from these marls is difficult.

Sponge-microbial bioherms and biostromes

(Młynka, Zalas) (Fig. 5)

Ammonites are dominated by the perisphinctids, which attain diameters of $2-20 \mathrm{~cm}$. Domination of small forms may be a sampling effect: finding large ammonites is more difficult in hard rocks than in platy limestones or marls. The top parts of some bioherms are covered by accumulations of small (up to $3 \mathrm{~cm}$ ) ammonites (Hoffmann and Matyszkiewicz 1989). Macroscopic observations of rock slabs and analysis of thin sections revealed the presence of abraded and fragmented ammonites (Fig. 5b). Such ammonites are relatively rare within biostromes in Zalas, but more common in bioherms and particularly associated with them detrital limestones in Młynka, where ammonite fragments occur mostly within clasts of eroded bioherms.

Ammonites strongly embedded in hard limestone are internal moulds with shells preserved by calcite cement (no clear evidence for the presence of pseudosparite) filling moldic porosity (moldic shell) (Fig. 5c). Thinning of shell whorls occur locally (Fig. 5e). Ammonite shells are dull in $\mathrm{CL}$ view. Ammonites are commonly encrusted by microbialites, mostly micropeloidal or peloidal-agglutinated laminated crusts, and by nubecularid foraminifera (Fig. 5c), serpulids, T. lapilloides and rarely bryozoans. External wall may contain abundant microborings (Fig. 5d). Apart from microbialites, sedimentary matrix within sponge-microbial limestones is peloidal-bioclastic packstone to grainstone. Similar sediment, and microbialites, occur within phragmocone chambers. The calcite cement within some inner ammonite chambers clearly differs from those occurring in glauconitic marls, because only blocky spar occurs (Fig. 5a), and siliceous cement is rare. Shells completely filled only with cement were not found, and empty chambers occur sporadically (Fig. 5f).

Sponge-microbial nodular limestones (Zalas) (Fig. 6)

Ammonites are represented mostly by Perisphinctidae, and attain diameters up to $12 \mathrm{~cm}$. Creamy-reddish nodules commonly developed around sponges, and ammonites are surrounded by more marly and more reddish sediment (Fig. 6a). Ammonites are preserved as internal moulds with diagenetically altered shell. Commonly, some parts of walls and septa, particularly external wall, are removed (dissolved), thinned or disturbed (continuously or not) (Fig. 6b-d). Surrounding sediment matrix contains more bioclasts than sediment within ammonite chambers. Microbialites occur both on ammonites and within shell chambers.

\section{Grey marls (Młynka, Zalas) (Fig. 7)}

Abundant ammonites are represented by Cardioceratidae and Taramelliceratidae (Matyja and Tarkowski 1981; Głowniak and Matyja 2006). They attain diameters of $2-10 \mathrm{~cm}$. The calcite crystals building the diagenetically altered shell are rather sparite cement, not pseudosparite (Fig. 7). Under CL, ammonite shells show bright redorange luminescence. Chambers are filled with marly bioclastic wackestone (sponge spicules, foraminifera) and calcimudstone. Marly sediment within ammonites is lithified in contrast to surrounding marly host sediment. Patchy occurrence of small bioclasts (Fig. 7a) suggests the presence of small burrows within sediment fillings. Compaction is moderate. Shell deformations are usually continuous, resulting in deformation of septa (Fig. 7b). 

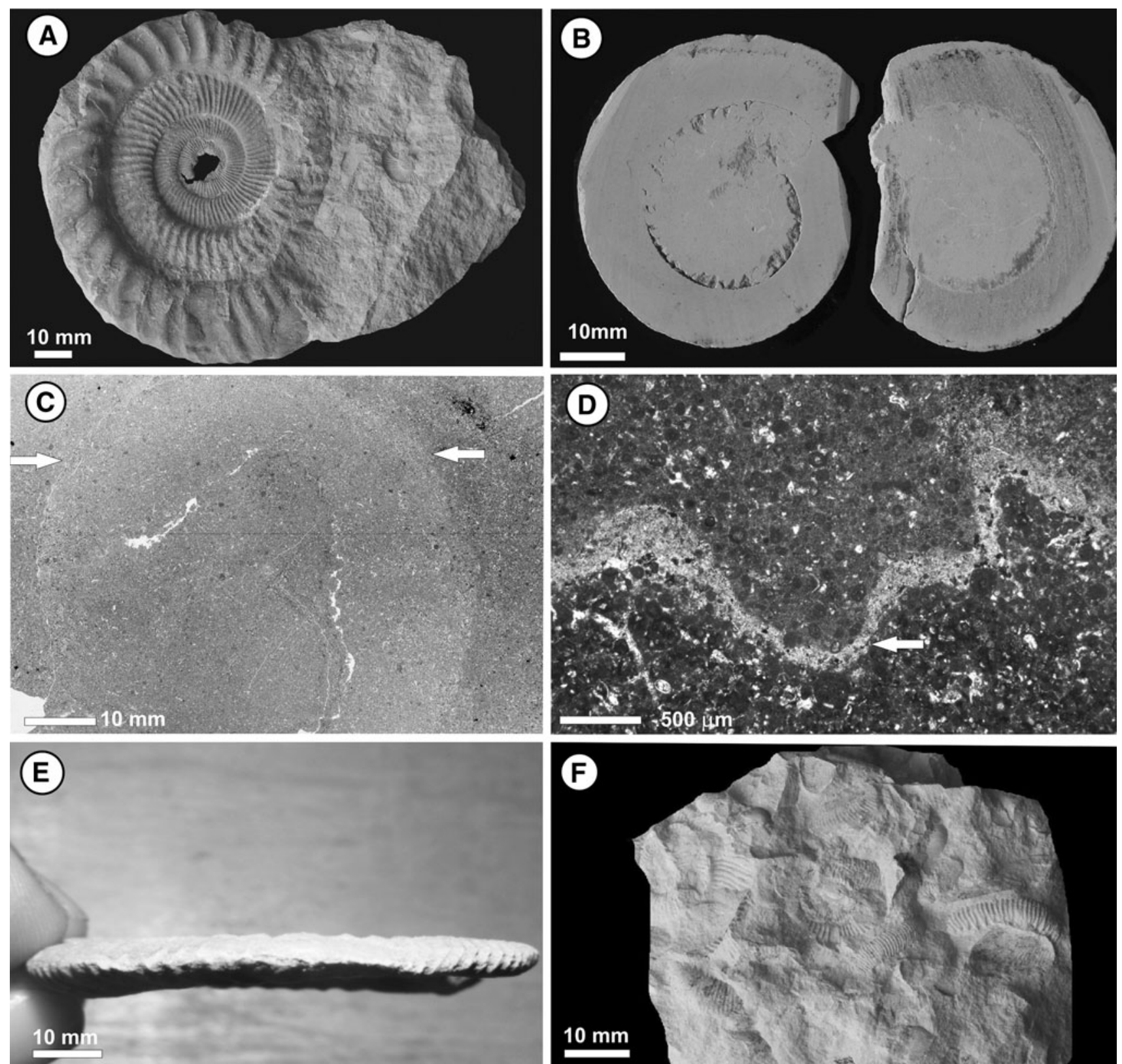

Fig. 4 Taphonomic features of ammonites from the Middle Oxfordian platy peloidal limestones, Młynka. a External mould of a perisphinctid ammonite. b Cut specimen revealing relics of the inner whorl wall. c Thin section showing ammonite marked in rock only by subtle differences between peloidal wackestone filling ammonite

\section{Discussion}

Ammonoid occurrences and their preservation traits were controlled by both palaeoecological and taphonomic processes. Differences in relative abundance, taxonomy and size between the Lower and Middle Oxfordian ammonites are palaeobiogeographical results of ammonite temporal incursions from Boreal and Mediterranean Provinces into the area of the Polish epicratonic basin

(arrows point to dissolved wall) and surrounding sedimentary matrix. d Thin-section image revealing subtle differences in sedimentary infilling of two ammonite chambers and relics of septal suture (arrow). e Highly compacted ammonite. f Chaotic concentrations of small ammonites

(e.g. Głowniak 2006). Abundant occurrence of ammonite shells and complete, non-hollow concretionary internal moulds in the Lower Oxfordian grey marls are related to sedimentological condensation. This phenomenon is linked with a well-known global crisis in carbonate sedimentation during the Late Callovian and Early Oxfordian. In the Cracow region this condensation persisted locally until the lower part of the Middle Oxfordian, which was possibly related to synsedimentary tectonics 

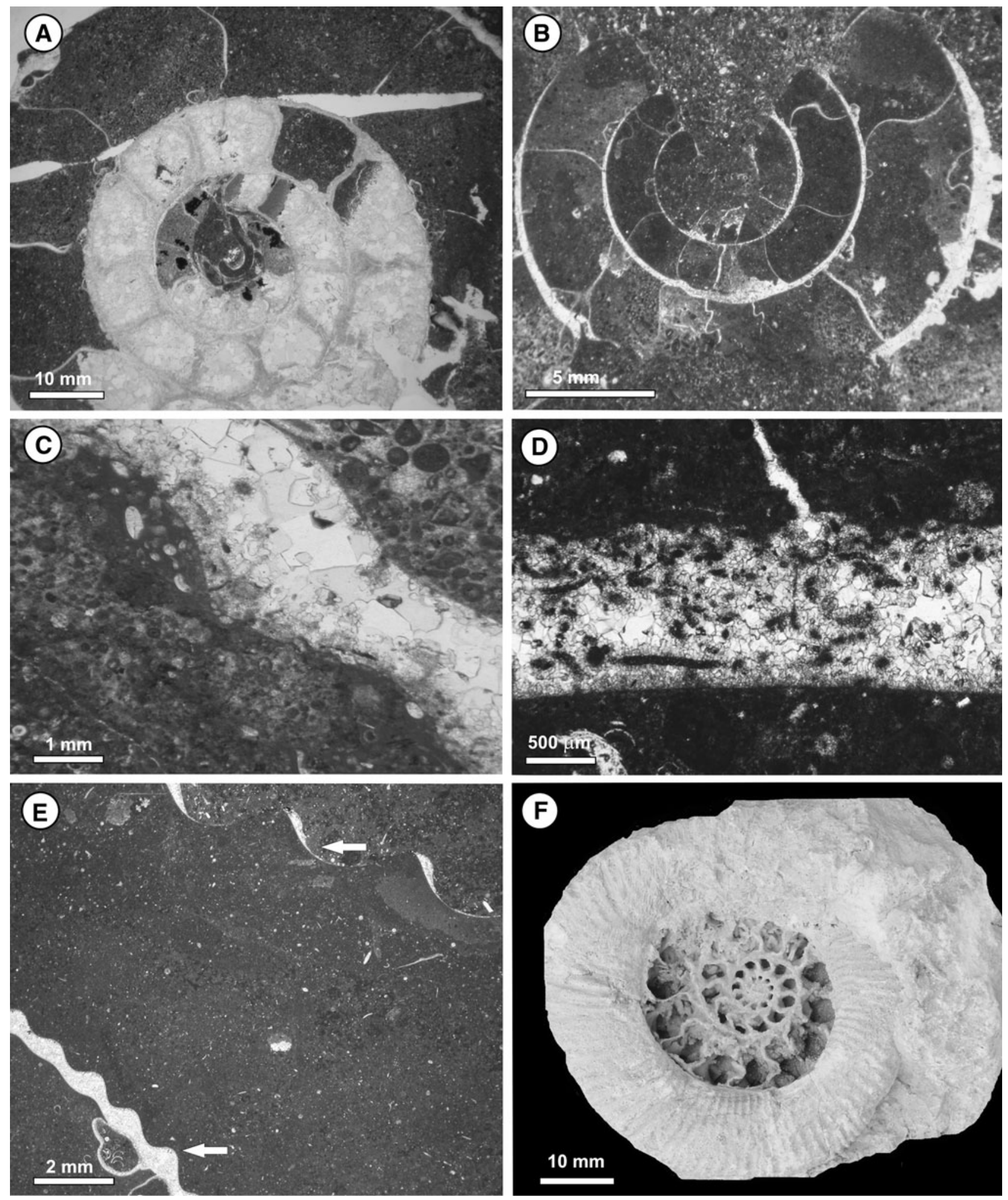

Fig. 5 Taphonomic features of ammonites from the Middle Oxfordian sponge-microbial limestones, Młynka (a-c, f) and Zalas (d, e). a Shell with the inner chamber filled with calcite cement. b Internal mould of ammonite showing abrasion facets. c Encrustation of nubeculariid foraminifera and microbial crust on the outer surface of

the shell built by calcite cement. d Microborings within the outer shell. e Wall of the inner whorl built by calcite cement (lower arrow); upper arrow points to disturbed, thinned outer shell. f Ammonite shell with empty inner chambers 

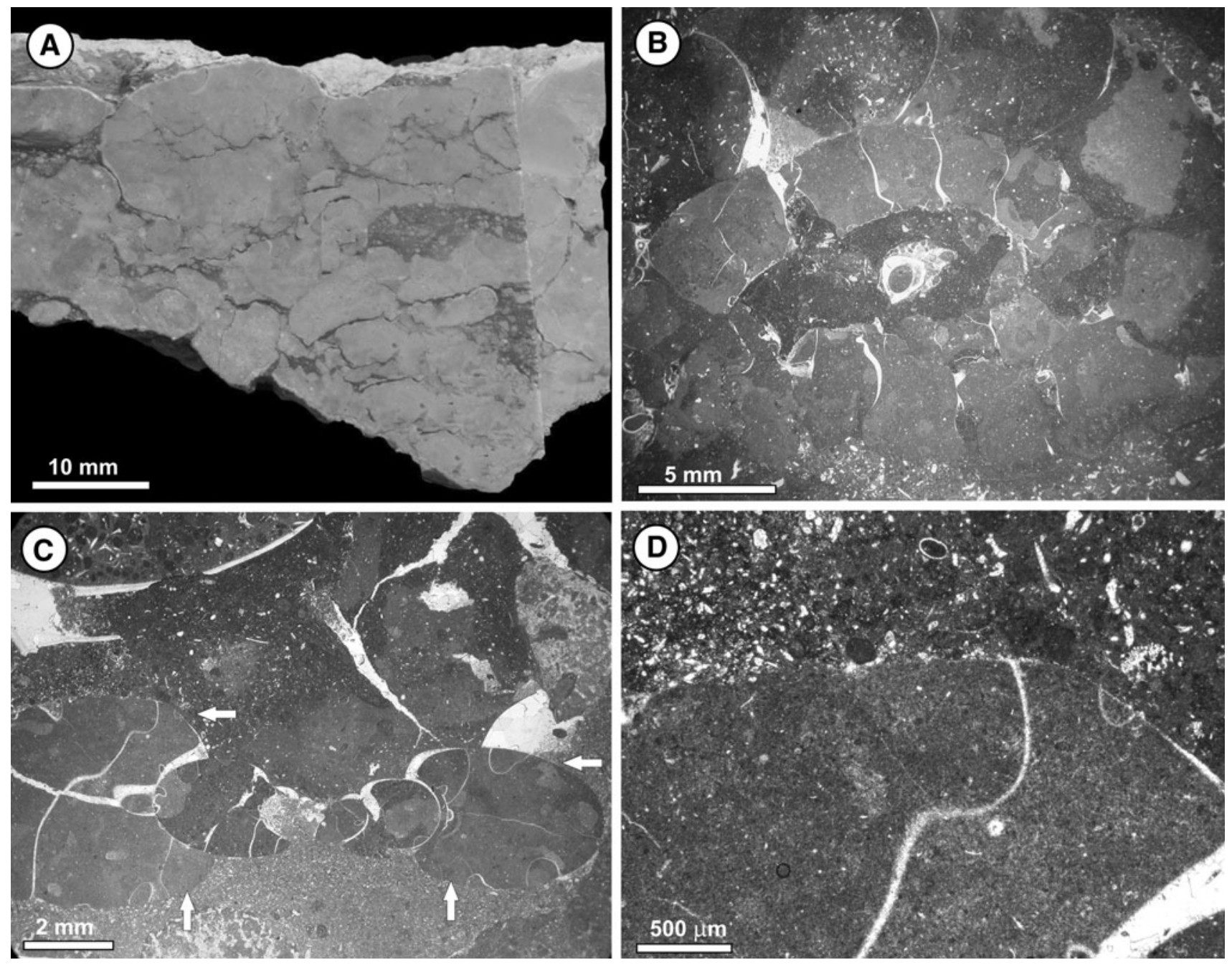

Fig. 6 Taphonomic features of ammonites from the Middle Oxfordian sponge-microbial nodular limestones, Zalas. a Polished rock slab showing nodular structure; nodules developed mostly around sponges and ammonites. b Strongly deformed ammonite shell with

(e.g. Giżejewska and Wieczorek 1977; Matyja and Tarkowski 1981; Hoffmann 1983; Hoffmann and Gradziński 2004; Matyja and Wierzbowski 2006). As discussed below, differential preservation of the studied specimens from five facies reflects mainly various parameters of the depositional environment: type and rate of sedimentation, hydrodynamics, oxygenation, microbial activity, timing of dissolution and cementation. These parameters are controlled biostratinomically, as well as by early and late diagenetic processes (Fig. 8).

Preservation of ammonite shells

Moderately low sedimentation rate of platy limestones, and particularly of grey marls, as well as slow cementation resulted in complete sedimentary filling of ammonite shells, without empty chambers or chambers filled only dissolved or thinned outer shell wall. c Ammonite shell with dissolved or thinned outer shell on its both sides (arrows). d Detail from $\mathbf{c}$

with cement. Domination of external moulds and high compaction of ammonites from platy limestones indicate slow cementation (cf. Seilacher et al. 1976). Ichnological analysis of platy limestones, including those from Młynka, revealed trace fossils typical for soft bottom, as well as those produced by late burrowers in firm sediment (Hoffmann and Uchman 1992). Local concentrations of small ammonites and/or fragments of large ammonites suggest high-energy events. Early partial dissolution of shells might made them more vulnerable to fragmentation even by poor currents or burrowing organisms. According to Hoffmann and Uchman (1992), trace fossils preserved in platy limestones were produced by deep-burrowing organisms, whereas shallower burrows were obliterated by intensive infaunal activity at the near-bottom layer. Shell fragments can also represent so-called kitchen middens (cf. Radwańska and Radwański 2004). 


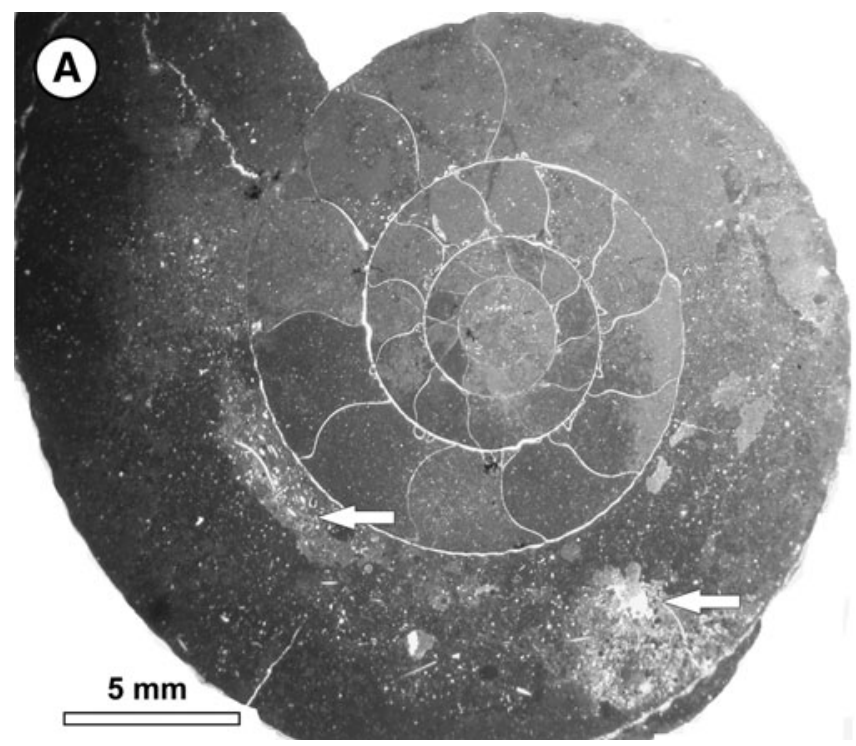

Fig. 7 Taphonomic features of ammonites from the Lower Oxfordian grey marls (Młynka). a Thin section through ammonite shell built by calcite cement. Sedimentary filling show patchy structures, partially

Differences in sediment filling (even subtle) in some ammonites from platy limestones indicate that dissolution of walls of inner whorls occurred after sedimentary filling. Sedimentary differences are more commonly recognizable between whorls than between phragmocone chambers. In such specimens, septa have been dissolved earlier, in preburial stage, forming in result hollow phragmocones (shells without septa; sensu Seilacher et al. 1976).

Ammonites from glauconitic marls (Podłęże) show differences in terms of compaction. The well-preserved, poorly compacted specimens from the museum collection indicate early lithification producing concretionary moulds. Some "closed" chambers remained empty until filled by cement during subsequent diagenetic stages. The presence of microbial crusts on some ammonites, as well as Frutexites structures within some chambers, suggest that lithification, at least partially, was microbially mediated. Frutexites microbial structure is known from deep-water stromatolites or cryptic habitats (Böhm and Brachert 1993). Changes in the rate of sedimentary accumulation and lithification may be inferred by the presence of strongly flattened ammonites too (Hoffmann 1983). Low rate of sedimentation of glauconite marls apart from stratigraphic condensation (Hoffmann 1983 ) is supported by the occurrence of microbial crusts and corrosion observed on one side of some ammonite shells. On the other hand, encrustations on both sides of some ammonites imply changes in hydrodynamics or activity of burrowing organisms. Because the museum ammonite collection from Podłęże contains mainly well-preserved specimens, deciphering of depositional dynamics is not possible without precise sampling in new outcrops.

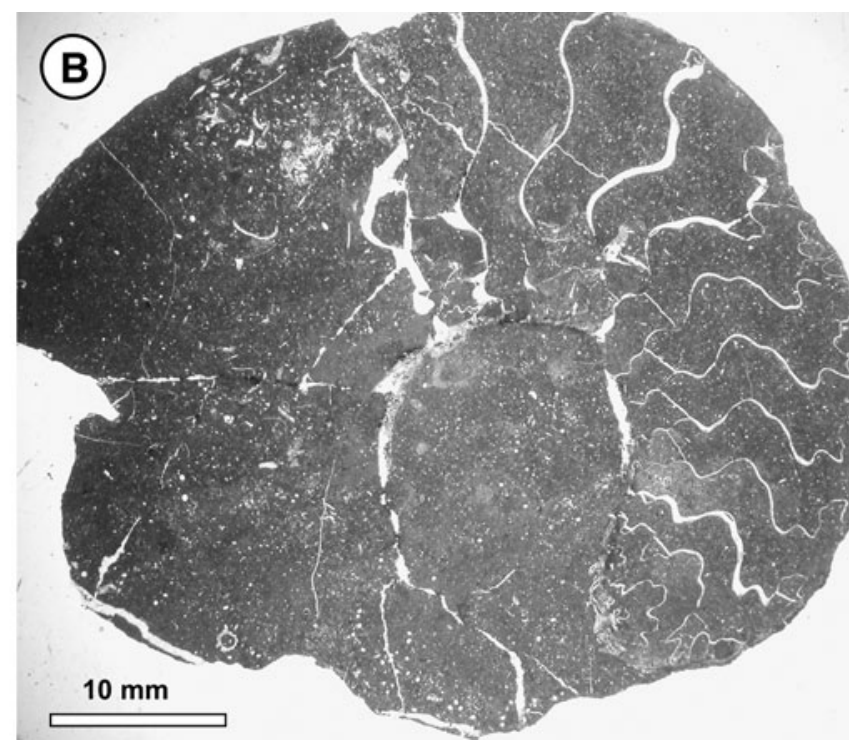

possible due to burrowing activity (arrow). b Ammonite shell with deformed or dissolved septa and innermost whorls

Microbial contribution to formation and early cementation of bioherms and biostromes (Młynka, Zalas) resulted in other ammonite taphonomic attributes in comparison with glauconitic marls. Although poorly compacted, the ammonites from sponge-microbial limestones can be deformed due to diagenetic dissolution. In particular, ammonites from sponge-microbial nodular limestones are strongly deformed and the external shell wall is commonly removed by dissolution under pressure. Late(?) diagenetic dissolution under pressure is also responsible for formation of nodules around ammonite shells and sponges. Nodular appearance of some sponge-microbial limestones, their reddish coloration and taphonomic features of ammonites may be related to diagenetic processes due to tectonics.

Ammonites from grey marls are poorly compacted, but numerous specimens show continuous and discontinuous deformations. The lack of ammonites in marly intercalations within platy limestones can be due to a decrease of carbonate production and enhanced clay input during a transient sea-level fall (cf. Pittet et al. 2000) or alternatively due to dissolution of aragonitic shells before infilling by sediment (e.g. Wright et al. 2003). Limestone-marl alternations may reflect differential diagenesis: aragonite dissolution in marly interlayers and cementation in limestone beds (e.g. Westphal et al. 2008). To decipher the environmental control or diagenetic overprint on fossil record, more extensive sampling from thin marly intercalations is required to make quantitative estimations of originally calcitic and aragonitic fossils.

Only ammonites from glauconitic marls contain neomorphic shells, i.e. shells which were not dissolved, but 

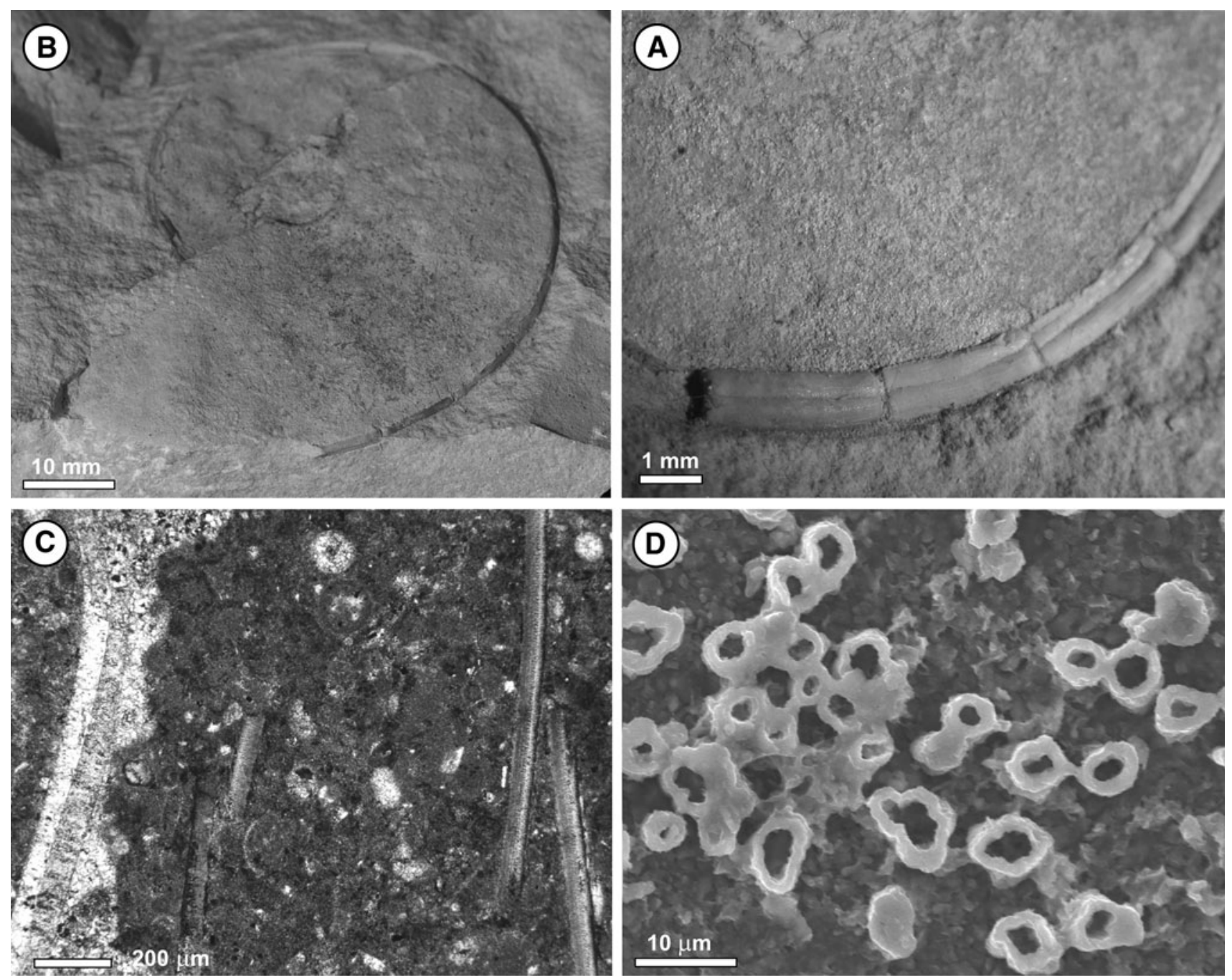

Fig. 8 Phosphatized siphuncular tubes from Młynka (a, b) and Podłęże (c, d). a Oppeliid shell with siphuncular tube attached to the outer wall (not preserved). b Compressed siphuncular tube with longitudinal crack along the middle part. c Thin-section image with

fragmented siphuncular tubes. Note neomorphic wall (left) built by pseudosparite with double layer structure. d SEM image of siphuncular tube with globular (bacterial?) structures

only affected by transformation from aragonite to calcite and recrystallization. These shells are hard to recognize macroscopically, therefore ammonites from these deposits were called moulds (Hoffmann 1983). Due to differences in original microstructures, as well as in the thickness of wall and septa, their original internal structure is better recognizable within wall than septa. The problem arises whether the calcite crystals in septa are pseudosparite or calcite cement. We suppose that most of skeletons were diagenetically transformed to neomorphic calcite, but it cannot be excluded that some skeletal parts, particularly septa, were preferentially dissolved. By contrast "diagenetic shells" of ammonites from other facies are built by calcite sparite cement, without evidence for neomorphic transformation. The means by which neomorphic shells occur only in glauconitic marls remain unclear. Some

authors noticed that aragonitic or neomorphic calcite shells of ammonites are preserved when encrusted by stromatolites (Pallini et al. 2003-2004; Myczyński and Jach 2009), which is the case of only some of ammonites from Podłęże.

Our observations revealed that using the term "external mould" may pose problems without thin-section analysis. Ammonites that, based on macroscopic observations, are termed as "external moulds" (walls and suture line not visible) may reveal under a microscope relics of diagenetically altered shells: external wall, wall of the inner whorls and/or septa. Due to common similarities in external and internal shell ornamentation, ammonites termed as external moulds can in fact reflect the ornamentation of the inner shell surface. A diagenetically altered shell either can be a neomorphic shell (aragonite transformed to calcite, relics of the original structure present) or is built by calcite 
cement filling moldic porosity (moldic shell) resulting from dissolution of the shell. In literature when the term "internal mould" is used it is commonly done without information on whether a diagenetically altered shell (or its relic) occurs or not. Also, if the term "neomorphic shell" is used, it is not clear whether the shell is the result of neomorphism, or the shell was dissolved and moldic porosity was subsequently filled with calcite cement; For example, Olóriz et al. (2004) alternatively used the terms "inner mould with neomorphic shell" and "inner mould with epigenetic shell". This latter term is used even when one can suppose that the shell is built rather by calcite cement and not by neomorphic (pseudosparite) calcite (see Olóriz et al. 2004, pl. 2, fig. E). Some ammonites have been described in literature as "internal moulds with occasionally preserved epigenized shells" (Caracuel et al. 2000, p. 361).

The term "external mould" should be applied to such replicas where the sediment filled the void after dissolution of the shell. If relics of the shell occur, or there are differences in sediment filling reflecting the position of inner whorls and septa, they can suggest that the mould in fact reflects inner shell ornamentation and the shell was dissolved in subsequent stages.

Difficulties with estimation of the type of mould are also due to the fact that some ammonites may be composite moulds; i.e. during burial diagenesis, external shell ornamentation is overprinted on the internal infillings (mould) (Macchioni 2000, p. 337). More studies are necessary to reveal whether some studied ammonites show such preservation.

Summarizing, the terms "internal moulds" and "external moulds" are commonly used in general to mean underlying the presence or lack of suture line and/or wall. However, literature review indicates that both terms are used also for ammonites with a more complex state of preservation. Thin-section observations are required to reveal whether the relics of shells are preserved. Such observations may provide information on whether the filling of the shell occurred before dissolution of septa and inner whorls (which may be marked only by subtle differences in filling material), or after their dissolution. Moreover, shells may be preserved as neomorphic shells or by calcite cement filling cavity resulting from shell dissolution (moldic shell).

\section{Phosphatization of siphuncular tubes}

Fossilized siphuncular tubes (siphuncles) were recognized only in glauconitic marls and platy limestones, although ammonites from these sediments differ in other taphonomic signatures. Calcium phosphate mineralogy of phosphatized siphuncular tubes was also recognized by
Andalib (1972), Hewitt and Westermann (1983), Hasenmueller and Hattin (1985), Kulicki (1996), Lukeneder (2001) and Kulicki et al. (2007).

Phosphatization of siphuncular tubes is interpreted as microbially mediated even though globular structures interpreted as bacteria were recognized only in a few tubes observed under SEM. Similar phosphatic spheroidal microbial structures were recognized for example in phosphatized soft tissue of horseshoe crabs (Briggs et al. 2005, fig. 4) or fish (Wilby and Briggs 1997, fig. 1; Briggs 2003, fig. 7).

Laboratory experiments have shown that phosphatization of soft tissues is favoured by closed, anoxic conditions, where the drop in $\mathrm{pH}$ induced by decay is sustained long enough to inhibit precipitation of $\mathrm{CaCO}_{3}$ (Briggs and Kear 1993, 1994). Such conditions can be reached by fast burial or overgrowth by microbial mats. The carcass itself may provide sufficient phosphorus for limited phosphatization of soft tissues, as revealed in experiments on shrimps (Briggs and Kear 1993, 1994). Briggs and Wilby (1996) and Wilby et al. (1996) showed that microbial mats played an important role in the phosphatization of soft tissues. Microbial mats may act as a barrier to diffusion of dissolved phosphorus, thus promoting apatite precipitation in a closed system. Microbial crusts were recognized on ammonites in glauconitic marls. Additionally, Frutexites structures observed in two ammonites suggest that microbes might have contributed to early cementation of the marly matrix. Microbialites are not known however from platy limestones. Spectacular, spheroidal, nannobacteria-like globules were recognized within carbonate matrix in both glauconitic marls and platy limestones. However, they were observed also in grey marls, as well as in other material studied by us, and are interpreted as sample etching artefacts (Kołodziej and Jurkowska 2011). Microbial mats promote closed microenvironment, thus phosphatization, but soft-tissue fossilization is a dynamic process, controlled by more than one set of sedimentary and geochemical parameters, and moreover may act on a very local scale such as animal carcasses (Briggs and Wilby 1996).

It is unclear why phosphatization of siphuncular tubes occurs only in some representatives of the Oppeliidae family, although analysed ammonites from Młynka and Podłęże show different taphonomic features, indicating different (at larger scale) depositional environments. Possible explanations for this taxonomic control include particular microenvironment within flattened, oxyconic shells of oppeliids or anatomical structure of their siphuncular tube, which-together with other factors-increased the chance for phosphatization. An additional explanation is that phosphatization occurred when carcasses were laid on the bottom during particular favourable environmental events (taphonomic window). 
Suggestions for further studies

More detailed taphonomic studies of ammonites as well as their host sediment may provide useful data on the depositional dynamics of the studied facies: changes in hydrodynamic energy, rate of sedimentation and associated environmental parameters. They may also allow estimation of the changes in sea water chemistry versus sedimentary environment and the influence on ammonite taphonomy. Taphonomic studies of ammonites-commonly reelaborated-from the uppermost Callovian and lowermost Oxfordian (not studied here) might provide a new tool in the interpretation of sedimentary and diagenetical history during different ammonite zones. It is worth underlining that preliminary observations of thin sections of ammonite shells from the condensed uppermost Callovian red marls (Zalas) revealed that they are built by neomorphic calcite sparite. This mode of preservation was observed in present studies only in ammonites from the Middle Oxfordian glauconitic marls.

Observations of ammonite shells under CL microscope indicate on additional tool in study of diagenesis of the ammonite-bearing facies. Different diagenetic history of the discussed facies is supported by CL observations of foraminifera (Kołodziej et al. 2011), and preliminary observations of ammonites (Jurkowska 2008). Abundant tests of planktonic foraminifera Globuligerina oxfordiana and most benthic forms from glauconitic marls, when observed in a CL microscope, show (like the studied ammonites) bright red-orange luminescence. In contrast, foraminifera and ammonite shells from sponge-microbial limestones and platy limestones (foraminifera observed only) are mostly dull in CL view.

Courville and Collin (2002) concluded from their work on taphonomic sequences that a similar taphonomic approach, especially analysis of ammonites, may be applied for other condensed sections at the Middle-Upper Jurassic boundary around the Tethyan margins, including Poland. Such taphonomic analysis should be necessarily performed together with biostratigraphic studies of ammonites.

\section{Conclusions}

1. Analysis of Lower (but not lowermost) and Middle Oxfordian ammonoids of the Cracow Upland revealed different taphonomic signatures of specimens from the Lower Oxfordian grey marls (Młynka, Zalas), Middle Oxfordian glauconitic marls (Podłęże), platy peloidal limestones (Młynka), sponge-microbial limestones (Młynka, Zalas) and sponge-microbial nodular limestones (Zalas).
2. Only in glauconitic marls do inner ammonite moulds have preserved neomorphic calcite shells. In grey marls, and sponge-microbial limestones, ammonite inner moulds contain "diagenetic" shell built by calcite cement filling moldic porosity. Ammonites from platy limestones reveal a more complex state of preservation. Usually they show features typical for external mould: walls of whorls and septa appear to be absent based on macroscopic observations. However, analysis of thin sections indicates that some of them have relics of wall and septa. Subtle differences in sediment filling indicate that sedimentary filling occurred, in some ammonites, before dissolution of inner whorls and even septa. Slow lithification of platy limestones influenced the strong shell dissolution and the highest degree of compaction of ammonites.

3. Phosphatized siphuncular tubes occur only in glauconitic marls and platy limestones, despite differences in other taphonomic attributes of ammonites. Microbially mediated phosphatization was possibly favoured by closed, anoxic conditions and a drop in $\mathrm{pH}$. Such a taphonomic phosphatization window occurred rather at the scale of ammonite carcasses and appears to be taxonomically controlled, because phosphatized tubes occur exclusively in specimens of the family Oppeliidae.

4. Taphonomic attributes of ammonites were controlled by sedimentary environment (type and rate of sedimentation, hydrodynamics, oxygenation, microbial activity, timing of dissolution and cementation), resulting in lithology that influenced early and late diagenesis.

5. Our results show that ammonites from the studied rocks, described in the literature as external and internal moulds, represent a more complex state of preservation. Further studies of ammonite taphonomy, particularly on ammonites from the condensed uppermost Callovian-lowermost Oxfordian sequences of the Cracow region, may be a useful tool for sequence stratigraphy.

Acknowledgments We thank Mariusz Hoffmann (Bielsko-Biała/ Warszawa) for access to his collection of ammonites from Podłęże, Michał Gradziński (Kraków) for valuable comments on the first draft of the manuscript and Agnieszka Ciurej (Kraków) for assistance with English. We acknowledge Sixto R. Fernández-López (Madrid) and Günter Schweigert (Stuttgart) for their constructive critical reviews that helped to improve this paper.

Open Access This article is distributed under the terms of the Creative Commons Attribution License which permits any use, distribution, and reproduction in any medium, provided the original author(s) and the source are credited. 


\section{References}

Allison, P.A., and D.J. Bottjer (eds.). 2011. Taphonomy: process and bias through time, vol. 32, 599. New York: Springer.

Andalib, F. 1972. Mineralogy and preservation of siphuncles in Jurassic cephalopods. Neues Jahrbuch fur Geologie und Paläntologie Abhandlungen 140: 33-48.

Behrensmeyer, A.K., S.M. Kidwell, and R.A. Gastaldo. 2000. Taphonomy and paleobiology. Paleobiology 26: 103-147.

Böhm, F., and T.C. Brachert. 1993. Deep-water Stromatolites and Frutexites Maslov from the Early and Middle Jurassic of S-Germany and Austria. Facies 28: 145-168.

Brett, C.E., and G.C. Baird. 1986. Comparative taphonomy: A key to paleoenvironmental interpretation based on fossil preservation. Palaios 1: 207-227.

Briggs, D.E.G. 2003. The role of decay and mineralization in the preservation of soft-bodied fossils. Annual Review of Earth and Planetary Sciences 31: 275-301.

Briggs, D.E.G., and A.J. Kear. 1993. Fossilization of soft-tissue in the laboratory. Science 259: 1439-1442.

Briggs, D.E.G., and A.J. Kear. 1994. Decay and mineralization of shrimps. Palaios 9: 431-456.

Briggs, D.E.G., R.A. Moore, J.W. Shultz, and G. Schweigert. 2005. Mineralization of soft-part anatomy and invading microbes in the horseshoe crab Mesolimulus from the Upper Jurassic Lagerstätte of Nusplingen, Germany. Proceedings of the Royal Society B 272: 627-632.

Briggs, D.E.G., and P.R. Wilby. 1996. The role of the calcium carbonate-calcium phosphate switch in the mineralization of soft-bodied fossils. Journal of the Geological Society 153: 665-668.

Caracuel, J.E., P. Monaco, and F. Olóriz. 2000. Taphonomic tools to evaluate sedimentation rates and stratigraphic completeness in Rosso Ammonitico facies (Epioceanic Tethyan Jurassic). Rivista Italiana di Paleontologia e Stratigraphia 106: 353-368.

Cariou, E., R. Enay, F. Atrops, P. Hantzpergue, D. Marchand, and M. Rioult. 1997. Oxfordien. In Groupe Français d'Etude du Jurassique-Biostratigraphie du Jurassique Ouest Europeèn et Mèditerranèen: zonations parallèles et distribution des invertébrès et microfossiles, coord. É. Cariou and P. Hantzpergue. Bulletin du Centre de Recherche Elf Exploration et Production, Mèmoire 17: 79-86.

Courville, P., and P.Y. Collin. 2002. Taphonomic sequences-A new tool for sequence stratigraphy. Geology 30: 511-514.

Dembicz, K., and T. Praszkier. 2007. Kelowej południowo-wschodniej części Jury Krakowsko-Częstochowskiej. Tomy Jurajskie 4: $71-76$.

Dżułyński, S. 1952. The origin of the Upper Jurassic limestones in the Cracow area. Rocznik Polskiego Towarzystwa Geologicznego 21: 125-180 (in Polish with English summary).

Fernández-López, S. 2000. Ammonite taphocycles in carbonate epicontinental platforms. In Advances in Jurassic research 2000, vol. 6, ed. R.L. Hall, and P.L. Smith, 293-300. Zürich: Trans Tech.

Fernández-López, S.R. 2007. Ammonoid taphonomy, palaeoenviroments and sequence stratigraphy at the Bajocian/Bathonian boundry on the Bas Auran area (Subalpine Basin, south-eastern France). Lethaia 40: 377-391.

Fernández-López, S.R. 2011. Taphonomic analysis and sequence stratigraphy of the Albarracinites beds (lower Bajocian, Iberian range, Spain). An example of shallow condensed section. Bulletin de la Société géologique de France 182: 405-415.

Fernández-López, S., and G. Meléndez. 1995. Taphonomic gradients in Middle Jurassic ammonites of the Iberian Range (Spain). Geobios 18: 155-165.
Fernández-López, S.R., and G. Meléndez. 2004. Fossilization of ammonites and sedimentary events in deep environments of carbonate platform (highest Middle to lowest Upper Oxfordian, Iberian Range, Spain). Rivista Italiana di Paleontologia $e$ Stratigrafia 110: 219-230.

Giżejewska, M., and J. Wieczorek. 1977. Remarks on the Callovian and Lower Oxfordian of the Zalas area (Cracow Upland, Southern Poland). Bulletin de l'Académie Polonaise des Sciences, Série Sciences des Sciences de la Terre 24: 167-175.

Głowniak, E. 2002. The ammonites of the family Perisphinctidae from the Plicatilis zone (lower Middle Oxfordian) of the Polish Jura Chain (Central Poland); their taxonomy, phylogeny and biostratygraphy. Acta Geologica Polonica 52: 307-364.

Głowniak, E. 2006. The Platysphinctes immigration event: Biostratigraphic and palaeoblogeographic implications for the Middle Oxfordian (Late Jurassic) seas of Central Europe (NW Germany and Poland). Neues Jahrbuch fur Geologie und Paläntologie Abhandlungen 241: 155-201.

Głowniak, E., and B.A. Matyja. 2006. Młynka quarry. Lower to lower Middle Oxfordian. In Jurassic of Poland and adjacent Slovakian Carpathians. Field trip guidebook of 7th international congress on the Jurassic system. Kraków, September, 6-18 2006, ed. A. Wierzbowski, R. Aubrecht, J. Golonka, J. Gutowski, M. Krobicki, B.A. Matyja, G. Pieńkowski, and A. Uchman, 138-141.

Gradziński, R. 1993. Geological map of Cracow region without quaternary and terrestrial tertiary deposits. Kraków: Muzeum Geologiczne, Instytut Nauk Geologicznych PAN.

Hasenmueller, W.A., and D.E. Hattin. 1985. Apatitic connecting rings in moulds of Baculites sp. from the middle part of the Smoky Hill Member, Niobrara Chalk (Santonian), of western Kansas. Cretaceous Research 6: 317-330.

Hewitt, R.A., and G.E.G. Westermann. 1983. Mineralogy, structure and homology of ammonoid siphuncles. Neues Jahrbuch fur Geologie und Paläntologie Abhandlungen 165: 378-396.

Hoffmann, M. 1983. Stratygrafia jury okolic Mirowa i Podtęża. M.Sc. thesis. Kraków: Jagiellonian University (in Polish).

Hoffmann, M., and M. Gradziński. 2004. Facies variation in Callovian deposits of the Kraków region (southern Poland) as an effect of basement topography and synsedimentary tectonic activity. In 23rd IAS meeting of sedimentology, abstract book, Coimbra, 15-17 September 2004, ed. R. Pena dos Reis, P. Callapez, and P. Dinis, 144.

Hoffmann, M., and J. Matyszkiewicz. 1989. Wykształcenie litologiczne i sedymentacja osadów jury w kamieniołomie Młynka. In Przewodnik LX Zjazdu Polskiego Towarzystwa Geologicznego, Kraków 14-16 września 1989, ed. J. Rutkowski, 78-83. Kraków: Polskie Towarzystwo Geologiczne (in Polish).

Hoffmann, M., and A. Uchman. 1992. Trace fossils from Oxfordian platy limestones nearby Kraków. Przeglad Geologiczny 11: 651-656 (in Polish, English summary).

Jurkowska, A. 2008. Tafonomia i paleoekologia amonitów z osadów oksfordu okolic Krakowa. M.Sc. thesis. Kraków: Jagiellonian University (in Polish).

Kin, A. 2008. Biostratygrafia amonitowa skondensowanych utworów oksfordu w Podłężu koło Krakowa. In Pierwszy Polski Kongres Geologiczny, Kraków 26.06.2008-28.06.2008, Abstrakty, ed. G. Haczewski, 52. Kraków: Polskie Towarzystwo Geologiczne (in Polish).

Kołodziej, B., and A. Jurkowska. 2011. Spheroidal, nanobacteria-like objects as possible sample etching artifacts. In 10th international symposium on fossil algae, Cluj-Napoca, 12-18 September 2011, Abstracts, ed. I.I. Bucur, and E. Săsăran, 39-40. Cluj-Napoca: Presa Universitară Clujeană. 
Kołodziej, B., A. Jurkowska, M. Banaś, and D. Ivanova. 2011. Improving detection of foraminifera by cathodoluminescence. Facies 57: 571-578.

Kulicki, C. 1996. Ammonoid shell microstructure. In Topics in geobiology, vol. 13, ed. N.H. Landman, K. Tanabe, and R.A. Davis, 65-101. New York: Plenum.

Kulicki, C., K. Tanabe, and N.H. Landman. 2007. Primary structure of the connecting ring of ammonoids and its preservation. Acta Palaeontologica Polonica 52: 823-827.

Lukeneder, A. 2001. Siphuncle structures in Barremian (Lower Cretaceous) ammonites from Austria. Annalen des Naturhistorischen Museums in Wien 102A: 69-83.

Lukeneder, A. 2005. Taphonomy and stratigraphy of Early Creataceous ammonoid mass occurrences (Late Valanginian; Nothern Calcareous Alps; Upper Austria). International Journal of the Austrian Geological Society 98: 34-51.

Macchioni, F. 2000. Bioeroded and/or encrusted ammonite moulds and their taphonomic implications. Rivista Italiana di Paleontologia e Stratigrafia 3: 337-352.

Maeda, H., T. Kumagae, H. Matsuoka, and Y. Yamazaki. 2010. Taphonomy of large Canadoceras (Ammonoid) shells in the upper cretaceous series in South Sakhalin, Russia. Paleontological Research 14: 56-68.

Maeda, H., and A. Seilacher. 1996. Ammonoid taphonomy. In Ammonoid paleobiology, ed. N.H. Landman, K. Tanabe, and R.A. Davis, 543-578. New York: Plenum.

Matyja, B.A. 2006. Stop A17-Zalas Quarry-Callovian transgressive to condensed pelagic deposits, lower to lowermost Middle Oxfordian deposits of sponge megafacies. In Jurassic of Poland and adjacent Slovakian Carpathians. Field trip guidebook of 7th international congress on the Jurassic system. Kraków, September, 6-18 2006, ed. A. Wierzbowski, R. Aubrecht, J. Golonka, J. Gutowski, M. Krobicki, B.A. Matyja, G. Pieńkowski, and A. Uchman, 70-72.

Matyja, B.A., and R. Tarkowski. 1981. Lower and Middle Oxfordian ammonite biostratigraphy at Zalas in the Cracow Upland. Acta Geologica Polonica 31: 1-14.

Matyja, B.A., and A. Wierzbowski. 2006. The oceanic "Metis Geotectonic Event" (Callovian/Oxfordian) and its implications for the peri-Tethyan area of Poland. Volumina Jurassica 4: $60-61$.

Matyszkiewicz, J. 1997. Microfacies, sedimentation and some aspects of diagenesis of Upper Jurassic sediments from the elevated part of the Northern peri-Tethyan Shelf: A comparative study on the Lochen area (Schwäbische Alb) and the Cracow area (CracowWieluń Upland, Poland). Berliner Geowissenschaftliche Abhandlungen E21: 1-111.

Matyszkiewicz, J., A. Kochman, and A. Duś. 2012. Influence of local sedimentary conditions on development of microbialites in the Oxfordian carbonate buildups from the southern part of the Kraków-Częstochowa Upland (South Poland). Sedimentary Geology 263-264:109-132.

Matyszkiewicz, J., M. Krajewski, B. Gołębiowska, J. Jędrys, A. Kochman, and G. Rzepa. 2007. Rozwój i ewolucja oksfordzkich budowli węglanowych w Zalasie. Tomy Jurajskie 4: 77-86.

Myczyński, R., and R. Jach. 2009. Cephalopod fauna and stratigraphy of the Adnet type reddeposits of the Krížna unit in the Western
Tatra Mountains, Poland. Annales Societatis Geologorum Poloniae 79: 27-39.

Ogg, J.G., J. Wieczorek, M.B. Steiner, and M. Hoffmann. 1991. Jurassic magnetostratigraphy, 4. Early Callovian through Middle Oxfordian of the Kraków Uplands (Poland). Earth and Planetary Science Letters 104: 488-504.

Olivero, E. 2007. Taphonomy of ammonites from the SantonianLower Campanian Santa Marta Formation, Antarctica: Sedimentological controls on vertically embedded ammonites. Palaios 22: 586-597.

Olóriz, F., M. Reolid, and F.J. Rodríguez-Tovar. 2004. Taphonomy of ammonite assemblages from the Middle-Upper Oxfordian (Transversarium?-Bifurcatus zones) in the Internal Prebetic (Betic Cordillera, Southern Spain): Taphonic populations and taphofacies to support ecostratigraphic interpretations. Rivista Italiana di Paleontologia e Stratigraphia 110: 239-248.

Pallini, G., S. Elmi, and F. Gasparini. 2003-2004. Late Toarcian-Late Aalenian ammonites assemblage from Mt. Magaggiaro (Western Sicily, Italy). Geologica Romana 37: 1-66.

Pittet, B., A. Strasser, and E. Mattioli. 2000. Depositional sequences in deep-shelf environments: A response to sea-level changes and shallow-platform carbonate productivity (Oxfordian, Germany and Spain). Journal of Sedimentary Research 70: 392-407.

Radwańska, U., and A. Radwański. 2004. Disease and trauma in Jurassic invertebrate animals of Poland-An updated review. Tomy Jurajskie 2: 99-111 (in Polish, English abstract).

Seilacher, A., F. Andalib, G. Dietl, and H. Gocht. 1976. Preservational history of compressed Jurassic ammonites from Southern Germany. Neues Jarbuch für Geologie und Paläontologie, Abhandlungen 152: 307-356.

Speyer, S.E., and C.E. Brett. 1988. Taphofacies models for epeiric sea environments: Middle Paleozoic examples. Palaeogeography, Palaeoclimatology, Palaeoecology 63: 225-262.

Tarkowski, R. 1986. Analyse taphonomique d'une oryctocénose: Exemple de l'Oxforddien de Pologne. Bulletin Museumm National d'Histoire National de Paris 4 série 8: 247-255.

Wani, R. 2003. Taphofacies models for Upper Cretaceous ammonoids from the Kotanbetsu area, northwestern Hokkaido, Japan. Palaeogeography, Palaeoclimatology, Palaeoecology 199: 71-82.

Westphal, H., A. Munnecke, F. Böhm, and S. Bornholdt. 2008. Limestone-marl alternations in epeiric sea settings-witnesses of environmental changes, or of rhythmic diagenesis? In Dynamics of Epeiric Seas: Sedimentological, Paleontological and Geochemical Perspectives, ed. C. Holmden, and B.R. Pratt, Geological Association of Canada, Special Volume 48:389-406

Wilby, P.R., and D.E.G. Briggs. 1997. Taxonomic trends in the resolution of detail preserved in fossil phosphatized soft tissues. Geobios 20: 493-502.

Wilby, P.R., D.E.G. Briggs, P. Bernier, and C. Gaillard. 1996. Role of microbial mats in the fossilization of soft tissues. Geology 24: 787-790.

Wright, P., L. Cherns, and P. Hodges. 2003. Missing molluscs: Field testing taphonomic loss in the Mesozoic through early largescale aragonite dissolution. Geology 31: 211-214. 